\title{
Initiation and control of meiosis in hamster gonads in vitro
}

\author{
Wai-sum O and T. G. Baker* \\ M.R.C. Unit of Reproductive Biology, 2 Forrest Road, Edinburgh EHI $2 Q W$, and \\ * Department of Obstetrics \& Gynaecology, University of Edinburgh, \\ Edinburgh EH3 9ER, U.K.
}

Studies of fetal ovaries maintained in organ culture have shown that meiosis can proceed in vitro (Martinovitch, 1938; Borghese \& Venini, 1956; Baker \& Neal, 1973). However, if the ovaries are removed from the fetus before the onset of meiosis, the germ cells fail to undergo normal meiosis in culture and subsequently degenerate (mouse: Wolff, 1952; sheep: Mauléon, 1973; hamster : Challoner, 1975a). In the hamster, meiosis fails to occur if the ovaries are removed before the 15 th day of gestation, even if gonadotrophic hormones or maternal serum are added to the cultures, suggesting that an 'inductor' is required to initiate meiosis (Challoner, 1975a). However, the meiosis inducing factor has not been investigated further. Byskov (1974) grafted fetal ovaries into nude mice and showed that the external rete ovarii was necessary to 'trigger' the induction of meiosis in the germ cells. In the present study, the effect of the external rete ovarii on the initiation of meiosis in the hamster was studied in organ culture.

Golden hamsters (Mesocricetus auratus) were mated on the evening of pro-oestrus, the day following mating being designated Day 1 post coitum (p.c.). The animals were killed and fetuses were recovered on Days $12,13,14,15$ or 16 p.c.; the sex of the fetus was determined from the karyotype or from the presence of sex chromatin bodies in liver cell nuclei. The ovaries contained rete ovarii which was attached cranially to the cords of germ cells. Ovaries devoid of the extraovarian rete were obtained by trimming away the cranial part of the ovary together with the rete tubules. In the first experiment, ovaries with or without rete were maintained in culture. In the second experiment, ovaries with rete were cultured with testes recovered from fetuses of the same gestational age. As a control, testes from fetuses of similar age were cultured together. The technique of organ culture was essentially that reported by Baker \& Neal (1973). At the end of the period of culture, 3-16 days within each age group, the ovaries (still attached to the agar blocks) were fixed in Bouin's fluid for $3 \mathrm{hr}$ and were processed by standard dehydration and embedding procedures. Serial sections cut at $5 \mu \mathrm{m}$ were stained with haematoxylin and eosin.

The results from both experiments are summarized in Table 1. In hamster ovaries in vivo, meiosis starts on Day 15 p.c. and the oocytes reach the diplotene stage by about Day 9 after birth (Challoner, 1974). Day 12 and Day 13 p.c. ovaries with external rete ovarii, maintained for 6 days in culture, contained germ cells of which more than $90 \%$ had entered meiosis (P1. 1, Fig. 1). When ovaries with rete were cultured for 14 days most of the germ cells reached the diplotene stage of meiotic prophase (PI. 1, Fig. 2), but the organization of the follicular cells was poor compared with normal ovarian differentiation at an equivalent age in vivo. Day 12 and Day 13 p.c. ovaries without rete cultured for 4-6 days contained only a few germ cells at the leptotene stage, and the majority did not enter meiosis. After 8 days in culture, the oogonia and the oocytes became atretic and by the 12th day the ovarian tissue was almost devoid of germ cells and consisted mainly of somatic tissue (Pl. 1, Fig. 3). Ovaries recovered with or without rete on Days 14,15 or 16 p.c. contained germ cells which mainly progressed through meiosis to the diplotene stage within 12 days of culture, but once again the follicular development was poor compared with that in vivo. These results with ovaries cultured without rete are similar to those of Challoner (1975a) and show that the presence of the rete ovarii seems to be essential for the initiation of meiosis of hamster germ cells in culture.

In the second experiment, the gonads were cultured in close apposition in a small depression made in agar blocks. The control (testis + testis) cultures developed normally, and meiosis did not begin in the seminiferous tubules (Pl. 1, Fig. 4). In the ovary + testis cultures, ovarian development was normal, with the germ cells undergoing meiotic division up to the diplotene stage. However, in the testicular part, the tubular structure was disorganized after 4 days in culture. The somatic cells pro- 
Table 1. Meiosis of fetal hamster gonads in organ culture

\begin{tabular}{|c|c|c|c|c|c|}
\hline & \multicolumn{5}{|c|}{ Gestational age at culture (days p.c.) } \\
\hline & 12 & 13 & 14 & 15 & 16 \\
\hline Duration of culture (days) & $6-16$ & $5-14$ & $4-12$ & $3-10$ & $3-10$ \\
\hline $\begin{array}{l}\text { Ovary with rete } \\
\text { No. of cultures } \\
\text { No. of ovaries with meiosis* }\end{array}$ & $\begin{array}{l}4 \\
4\end{array}$ & $\begin{array}{l}4 \\
4\end{array}$ & $\begin{array}{l}5 \\
5\end{array}$ & $\begin{array}{l}5 \\
5\end{array}$ & $\begin{array}{l}3 \\
3\end{array}$ \\
\hline $\begin{array}{l}\text { Ovary without rete } \\
\text { No. of cultures } \\
\text { No. of ovaries with meiosis* }\end{array}$ & $\begin{array}{l}4 \\
0\end{array}$ & $\begin{array}{l}4 \\
0\end{array}$ & $\begin{array}{l}5 \\
5\end{array}$ & $\begin{array}{l}5 \\
5\end{array}$ & $\begin{array}{l}3 \\
3\end{array}$ \\
\hline $\begin{array}{l}\text { Ovary with rete }+ \text { testis } \\
\text { No. of cultures } \\
\text { No. of ovaries with meiosis* } \\
\text { No. of testes with meiosis } \dagger\end{array}$ & $\begin{array}{l}6 \\
6 \\
6\end{array}$ & $\overline{-}$ & $\begin{array}{l}8 \\
8 \\
8\end{array}$ & $\begin{array}{l}3 \\
3 \\
3\end{array}$ & $\begin{array}{l}6 \\
6 \\
6\end{array}$ \\
\hline $\begin{array}{l}\text { Testis + testis } \\
\text { No. of cultures } \\
\text { No. of testes with meiosis }\end{array}$ & $\begin{array}{l}4 \\
0\end{array}$ & - & $\begin{array}{l}9 \\
0\end{array}$ & $\begin{array}{l}9 \\
0\end{array}$ & $\begin{array}{l}6 \\
0\end{array}$ \\
\hline
\end{tabular}

* At least $90 \%$ of surviving germ cells undergoing meiosis.

† About $30 \%$ of surviving germ cells undergoing meiosis.

liferated and surrounded the germ cells either individually or in small groups (Pl. 1, Fig. 5). These 'isolated' male germ cells entered meiosis precociously and some reached the diplotene stage of meiotic prophase (Pl. 1, Fig. 6). These results suggest that a meiosis-initiating factor, derived from the rete ovarii, can influence the development of germ cells in the testis as well as in the ovary. The possibility of migration of germinal and/or somatic cells between the ovary and testis cannot be ruled out at present but seems unlikely from the distribution of meiotic cells seen in the gonads.

These findings support the contention of Byskov (1974) that an ovarian factor, probably derived from the rete ovarii, triggers the onset of meiosis in female germ cells. Whether this depends on direct cellular contact between the rete and the germ cells or on a diffusible substance remains to be determined. Secretory activity has been reported in the rete tubules of the dog (O'Shea, 1966), cat (Mossman, 1969), and heifer (Archbald, Schultz, Fahning, Kurtz \& Zemjanis, 1971). The rete cells actively secrete a PAS-positive substance at the stage when meiosis commences in the ovaries of the cat, mink and ferret (Byskov, 1975). The secretory substance has yet to be characterized, but when the fetal hamster ovary with rete attached was separated by a distance of about $2 \mathrm{~mm}$ from the fetal testis, testicular development was not affected and meiosis did not occur in male germ cells (W. O, unpublished observation). This indicates that if a diffusible factor is secreted by the rete, it only acts over a very short distance.

Transmission of morphogenetic signals between embryonic cells can also occur by means of intercellular contacts. It is known that cells from the spinal cord can cause the induction of mouse kidney cells. When the nervous tissue and kidney cells are separated by membrane filters, induction only occurs if cell-to-cell contact is established through the pores of the filter; no evidence for a diffusible substance was found (Wartiovaara, Nordling, Lehtonen \& Saxén, 1974; Saxén, Lehtonen, Karkinen-Jääskeläinen, Nordling \& Wartiovaara, 1976). Whether the rete cells and the germ cells interact by direct cytoplasmic contact remains to be investigated.

The rete ovarii is known to be influenced by hormones (man: Sauramo, 1954; heifer: Archbald et al., 1971) and we cannot exclude the possibility that the rete tubules may act as mediators between systemic hormones and the germ cells, although the culture medium used in our experiments contained little gonadotrophic activity (B. M. Hobson, personal communication). This low gonadotrophic activity in the culture medium also explains the poor follicular development in the cultured ovaries as it has been shown that gonadotrophins are essential for normal follicular development in hamsters in vitro (Challoner, 1975b). 

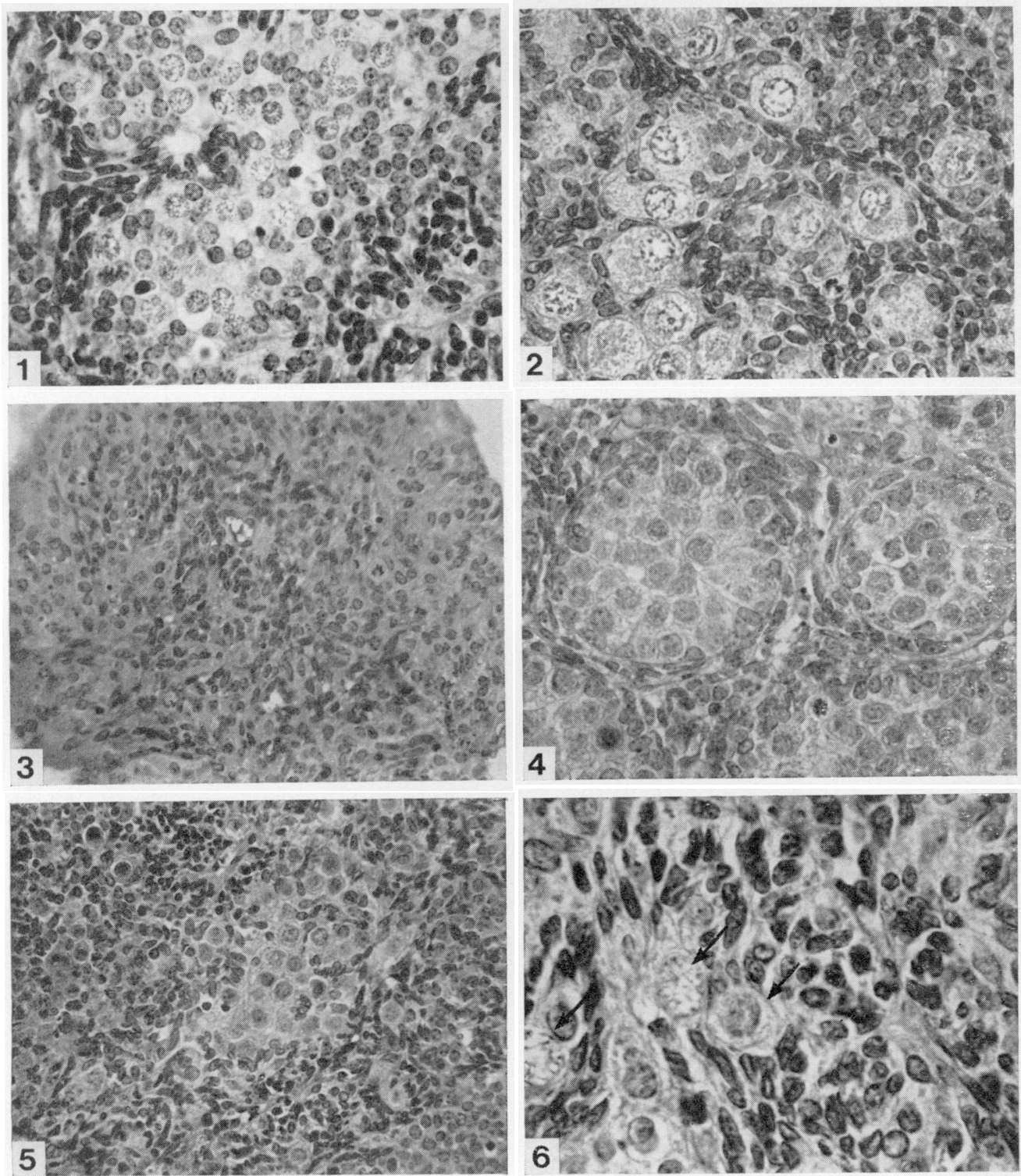

PLATE 1

Hamster gonads in culture.

Fig. 1. Ovary with rete ovarii at Day 13 p.c. and cultured for 7 days. The majority of oocytes are undergoing meiosis. $\times 580$.

Fig. 2. Ovary with rete ovarii at Day 14 p.c. and cultured for 12 days. Oocyles have reached the diplotene stage but follicular development is severely retarded. $\times 580$.

Fig. 3. Ovars without rete ovarii recovered on Day 12 p.c. and cultured for 12 days. Only somatic cells are present in the ovarian tissue. $\times 580$.

Fig. 4. Day 14 p.t. testis cultured for 12 dass. Seminiferous tubules and germ cells are well maintained. $\times 580$.

Iig. 5. Day 14 p.c. testis cultured for 8 days with ovary of the same age, and showing disorganization of the seminiferous tubules. $\times 150$.

Fig. 6. Day 14 p.c. testis cultured for 12 days with ovary of the same age. Note the large numbers of somatic cells and the male germ cells (arrowed) undergoing meiotic prophase. $\times 580$. 
Our results, showing an influence of the fetal ovary on the fetal testis, are at variance with those of earlier workers in vitro (rat and rabbit: Holyoke \& Beber, 1958) and in vivo (rat: MacIntyre, 1956; mouse: Turner, 1969), who claimed to have shown an effect of the testis on ovarian development. These differences may be due to the fact that, in the present study, the hamster testis was cultured with the ovary at a time when its rete ovarii was very active. However, it is not known whether the ovarian influence is directly on the male germ cells or if the action is on male somatic cells, the initiation of meiosis being due to isolation of the male germ cells. Further studies are necessary to define more precisely this key role of the rete ovarii in the initiation of meiosis in the germ cells.

The expenses incurred in this study were defrayed out of grants from the Population Council, New York, and the Medical Research Council. Wai-sum $O$ is also grateful to the Faculty of Medicine, University of Edinburgh for financial support.

\section{References}

Archbald, L.F., Schultz, R.H., Fahning, N.L., KuRTZ, H.J. \& ZEMJANIS, R. (1971) Rete ovarii in heifers: a preliminary study. J. Reprod. Fert. 26, $413-414$.

BAKER, T.G. \& NEAL, P. (1973) Initiation and control of meiosis and follicular growth in ovaries of the mouse. Annls Biol. anim. Biochim. Biophys. 13, 137-144.

Borghese, E. \& VeniNI, M.A. (1956) Culture in vitro de gonadi embrionali di Mus musculis. Symp. genet. 5, 69-83.

Byskov, A.G. (1974) Does the rete ovarii act as a trigger for the onset of meiosis? Nature, Lond. 252, 396397.

Byskov, A.G. (1975) The role of the rete ovarii in meiosis and follicle formation in the cat, mink and ferret. J. Reprod. Fert. 45, 201-209.

Challoner, S. (1974) Studies of oogenesis and follicular development in the golden hamster. 1. A quantitative study of meiotic prophase in vivo. J. Anat. 117, 373-383.

Challoner, S. (1975a) Studies of oogenesis and follicular development in the golden hamster. 2 . Initiation and control of meiosis in vitro. J. Anat. 119, 149-156.

Challoner, S. (1975b) Studies of oogenesis and follicular development in the golden hamster. 3. Initiation of follicular growth in vitro. J. Anat. 119, 157162.

Holyoke, E.A. \& Beber, B.A. (1958) Culture of gonads of mammalian embryos. Science, N.Y. 128, 1082.

MACINTYRE, M.N. (1956) Effect of the testis on ovarian differentiation in heterosexual embryonic rat gonad transplants. Anat. Rec. 124, 27-45.
MARTINovitch, P.N. (1938) Development in vitro of the mammalian gonad. Ovary and ovogenesis. Proc. $R$. Soc. B 125, 232-249.

Mauléon, P. (1973) Modification expérimentale de l'apparition et de l'évolution de la prophase méiotique dans l'ovarie d'embryon de brebis. Annls Biol. anim. Biochim. Biophys. 9, 475-481.

Mossman, H.W. (1969) A critique of our progress toward understanding the biology of the mammalian ovary. In Reproduction and Sexual Behaviour, pp. 187205. Ed. M. Diamond. Indiana University Press.

O'SHEA, J.D. (1966) Histochemical observations on mucin secretion by subsurface epithelial structures in the canine ovary. J. Morph. 102, 347-358.

SAURAMO, H. (1954) Development, occurrence, function and pathology of the rete ovarii. Acta obstet. gynec. scand., Suppl. 33, 29-46.

SAXÉN, L., LEHTONEN, E., KARKINEN-JÄÄSKELÄINEN, M., Nordling, S. \& WartiovaARA, J. (1976) Are morphogenetic tissue interactions mediated by transmissible single substances or through cell contacts? Nature, Lond. 259, 662-663.

TURNER, C.D. (1969) Experimental reversal of germ cells. Embryologia 10, 206-230.

WartiovaAra, J., Nordling, S., Lehtonen, E. \& SAXÉN, L. (1974) Transfilter induction of kidney tubules: correlation with cytoplasmic penetration into nucleopore filters. J. Embryol. exp. Morph. 31, 667-682.

WolfF, E. (1952) Sur la différentiation sexuale des gonades de souris explantées in vitro $C . r$. hebd. Séanc. Acad. Sci., Paris 234, 1712-1714.

Received 29 April 1976 